\title{
FAVELA TOUR: UM DELICADO EQUILÍBRIO DE FORÇAS
}

\author{
Bruna Aparecida Viola da Silva \\ Universidade do Estado do Rio de Janeiro - UERJ \\ Programa de Pós-Graduação em Geografia, Rio de Janeiro, RJ, Brasil \\ bruna.viola@globo.com
}

\begin{abstract}
RESUMO
No Rio de Janeiro a prática do turismo em favelas não é fenômeno recente, tem seus primeiros registros datados do início do século XX e cresceu a partir da espetacularização do espaço. Estigmatizadas pela violência e pela precariedade, estas favelas tiveram seu cotidiano amplamente explorado por ações midiáticas que, alidades à intervenção policial do Estado a partir da instalação das Unidades de Polícia Pacificadora, impulsionaram a prática do Favela Tour. Na Santa Marta, o processo de pacificação precedeu a institucionalização do turismo a partir da implementação do programa Rio Top Tour, idealizado pelo Estado com o intuito de atrair novos circuitos mercadológicos para o local, intitulado, à época, de "Favela Modelo". Atualmente, porém, a comunidade sofre os impactos do declínio da atividade turística em decorrência do aumento da violência e dos confrontos pela disputa do seu território e da descontinuidade das políticas de melhoria idealizadas a partir da possibilidade de transformar o morro em espaço fértil para a reprodução do capital.
\end{abstract}

Palavras-chave: Turismo. Favela. Estado. Violência. Capital. Espaço.

\section{FAVELA TOUR: A DELICATE BALANCE OF FORCES}

\begin{abstract}
In Rio de Janeiro the practice of tourism in shanty town is not a recent phenomenon. It has its first documentation dating from the beginning of the 20th century and had expanded from the spectacularisation of the space. Stigmatized by violence and precariousness, these shanty towns had their daily routine extensively exploited by media actions that, allied to the State police intervention through Pacific Police Units, boosted the Favela Tour practice. In Santa Marta's favela, the pacification process preceded the institutionalization of tourism through the implementation of the Rio Top Tour program designed by the Authorities to attract new financial channels to the community then named as "Favela Modelo". Currently the community is impacted by the decline in tourist activity as a result of increased violence as well as confrontation over the territorial dispute and the discontinuation of idealized improvement policies based on the possibility of transforming that place in fertile space for the reproduction of capital.
\end{abstract}

Keywords: Tourism. Shanty town. State. Violence. Capital. Space.

\section{INTRODUÇÃO}

A turistificação das favelas cariocas não é evento recente: foi apresentada e discutida na Conferência das Nações Unidas sobre o Meio Ambiente e o Desenvolvimento, a Eco-92, e cresceu vertiginosamente a partir da instalação das Unidades de Polícia Pacificadora (UPP). Alimentada pela intensa exposição midiática, seja pelos conflitos existentes na favela, seja pela consolidação desta como trademark (FREIRE-MEDEIROS, 2007) a prática tem motivações que vão da curiosidade à filantropia.

Localizada aos pés do Morro Dona Marta, em Botafogo (RJ), a praça Corumbá é mais do que espaço de convivência para seus moradores: é ali que os turistas se concentram antes de adentrarem a favela. Seja no entorno da cabine de informação turística, seja nos seus arredores apreciando as inúmeras opções gastronômicas, é possível observar a movimentação dos visitantes que contemplam, curiosos, uma das favelas mais verticalizadas da cidade. A proposta inicial deste trabalho era investigar o turismo na Rocinha - berço do programa que dá título ao trabalho, o Favela 
Tour - seus agentes, seu público, a relação dos moradores com a atividade e a forma como ela se organizava. Contudo, um intenso e extenso confronto entre narcotraficantes que brigavam pelo domínio daquele território tornou a pesquisa de campo inviável. Além dos riscos evidentes em realizar incursões pela favela naquelas condições, havia também o fato de que a atividade turística estava bastante escassa em função dos episódios de violência. Diante deste cenário, a Favela Santa Marta, ainda desfrutando de relativa paz se comparada à Rocinha, despontou como recorte espacial possível para a realização do trabalho. Barbosa, em 2014, apresentou em sua pesquisa intitulada "Um novo circuito na favela, o caso da frequentação turística no Santa Marta" sobre os aspectos diversos da prática do turismo após a implementação da UPP. A mudança de cenário ocorrida ao longo destes cinco anos justifica o retorno ao Morro com o intuito de analisar, sob uma nova perspectiva, a atividade turística diante do aumento dos confrontos violentos no local - daí a necessidade de investigar não apenas a atividade turística e seus desdobramentos, mas também os fatores que permitem que esta aconteça.

O processo turístico, tema central do artigo, demanda reflexões acerca de suas categorias conformativas envolvendo o capital, a ideologia e a própria produção do espaço. Tal processo, analisado a partir do pressuposto da materialidade social, é mediado e conformado pelas relações estabelecidas entre essas categorias, constituindo uma totalidade de complexidades que necessitam ser explicadas para além de um referencial fenomênico ou pelas formas da empiria. $O$ desenvolvimento capitalista que se firma histórica e geograficamente pela valorização do valor ou mais-valor concretiza o capital como relação social dominante, sendo inerente à sua lógica reprodutiva o espaço fragmentado que se materializa de maneiras diversas. Segundo Corrêa (2005, p. 144):

Essa fragmentação decorrente da ação dos diversos agentes modeladores que produzem e consomem espaço urbano: proprietários dos meios de produção, sobretudo os grandes industriais, proprietários fundiários, promotores imobiliários, Estado e grupos sociais excluídos. A ação desses agentes, que obedece a uma lógica que é simultaneamente própria e geral, produz os diferentes fragmentos que compõem o mosaico urbano

No ambiente urbano, o turismo enseja todo um conjunto de novas relações e práticas espaciais, incidindo diretamente na valorização da terra urbana e na produção de um novo mapa simbólico dos lugares. O processo de valorização tende a ser acentuado nos locais considerados turísticos, gerando expulsão de moradores e de determinados usos. A partir das proposições de Patrick Mullins em torno do conceito de urbanização turística, Mascarenhas (2004, p. 4) investiu na análise dos efeitos indesejáveis do turismo no processo de urbanização. Nas palavras do autor:

No Brasil, não obstante a evidência do fenômeno em pauta, raras tem sido as iniciativas acadêmicas para compreender as formas de urbanização turística. No plano teórico, destaca-se o pioneirismo de Maria Thereza Luchiari (1998), ao repensar a proposta de Mullins no marco conceitual proposto por Milton Santos, que estuda o lugar em sua relação com a totalidade-mundo.(...) Para ela (1998:28), corremos o risco de ver a urbanização turística produzir cidades tão indesejáveis quanto o fez a urbanização industrial.

A turistificação das favelas surge, inicialmente, de forma contraditória ao incentivar a extração valor a partir da desvalorização. De acordo com Freire-Medeiros (2006), em 1884 o Dicionário Oxford adotou o termo Slumming para designar as visitas a locais menos favorecidos. Os reality tour têm seu ponto de partida no desejo do turista por buscar o pitoresco e da necessidade de expansão do capital e a precariedade é o atrativo principal dessa prática, sustentada por alguns pilares construídos de forma interdependente, dentre eles: o imaginário do turista alimentado pela estereotipização e reforçado pelos meios de comunicação e a mercantilização do espaço através da apropriação do mesmo pela atividade turística. Assim, a análise das práticas como o Favela Tour demanda algumas variáveis que ultrapassam a esfera do mercado turístico, só podendo ser compreendidas a partir da contextualização histórica de seus elementos constitutivos.

No Rio de Janeiro, a formação e o desenvolvimento das favelas teve início a partir de uma série de fatores que consolidaram a cidade como mercadoria e resultaram num espaço repleto de verticalidades (Santos, 1996), cada vez mais desagregado. A ausência de medidas de reestruturação desse espaço, a qual faz parte da planificação mediada por uma racionalidade restritiva ao valorcapital, fez com que as favelas tomassem proporções cada vez maiores. Marcadas pela precariedade e pela negligência, foram, em grande parte, territorializadas pelo crime organizado e tiveram a violência incorporada ao seu cotidiano. É importante ressaltar que o nível de soberania do Estado nas favelas é visivelmente inferior ao existente no restante do espaço urbano - fato historicamente 
explicado pela pouca ou nenhuma atenção que a mesma recebeu do Poder Público (VALLADARES, 2000). Dessa forma, a relação de soberania que deveria existir nesses locais entre o Estado e a população passa a ser exercida diretamente pelo poder estabelecido através de determinados grupos armados.

Diante da necessidade do Estado de retomar o controle sobre esses espaços, surge, então, o projeto de pacificação através da implementação de Unidades de Polícia Pacificadora, uma ideia de policiamento comunitário. O objetivo primordial da instalação das UPPs nas favelas seria, antes de tudo, a retomada do território e a reafirmação do poder do Estado através da eliminação dos grupos criminosos e das formas de poder ali existentes, recuperando o controle sobre sua população, ainda que através da repressão. Nesse sentido, o conceito de soberania apresentado por Michel Foucault esclarece o papel do Estado e suas políticas de repressão representadas pela figura das UPPs, onde a principal função do soberano torna-se a necessidade de garantir a segurança da população sob o seu domínio. O soberano influenciado pelo desenvolvimento das instituições capitalistas, elaborará técnicas de controle disciplinar a serem empregadas sobre o corpo, o comportamento e o cotidiano dos indivíduos, com o objetivo de extrair a produtividade máxima que o domínio sobre os mesmos poderia oferecer ao sistema capitalista, graças ao poder exercido sobre eles. Assim, esclarece Foucault:

[...] já não seria soberano de direito ou em função de um direito, mas seria igualmente um soberano capaz de administrar, de administrar, é claro, os sujeitos sobre os quais ele exerce sua soberania, mas também os processos econômicos que podem se desenrolar entre os indivíduos, entre os grupos, entre os Estados. (FOUCAULT, 2008, p. 386)

O Estado amparado pelos meios de comunicação e pelo discurso de combate ao crime organizado, realiza a instalação das UPPs de forma arbitrária e por intermédio do emprego de uma polícia fortemente armada. A implementação das UPPs contempla, ainda, interesses do Estado submetido à lógica do capital, responsável por gerir o modo como será produzido e reproduzido o espaço urbano. Atendendo a um fenômeno global de transformação das cidades em cidades-mercadoria, a construção do espaço dentro dos parâmetros de uma imagem orientada segundo os interesses do mercado, torna esse mesmo espaço passível de investimento do capital privado. Assim, esclarece Franco (2014, p. 15) enquanto apresentava as premissas de sua pesquisa:

\begin{abstract}
"Para fazer essa reflexão, este estudo visa indicar os elementos de militarização e desenvolvimento do capitalismo, considerando os pontos de vista histórico, sociológico e tradições históricas. Diante dessa questão, surgiu a necessidade de situar a relação entre Estado e Sociedade. Para em seguida: o peso do discurso ideológico como instrumento para que se criasse um ambiente favorável para a consolidação de tal política. Ou seja, o financiamento privado para a implementação das UPPs, adicionado ao discurso ideológico de combate ao chamado tráfico de drogas, em um período de grandes eventos, indicam a possibilidade de desmanchar qualquer possibilidade de uma alteração significativa nas políticas públicas de segurança".
\end{abstract}

Tal medida atenderia também a um projeto maior de reestruturação territorial, visando preparar a cidade para a realização de dois megaeventos esportivos: a Copa do Mundo da Fifa de 2014 e os Jogos Olímpicos de 2016. Tendo a favela Santa Marta como laboratório, a primeira unidade da UPP foi instalada em 2008 e precedeu a criação do Rio Top Tour, projeto que prometia impulsionar o turismo no local através do trabalho da própria comunidade, valorização e profissionalização dos guias locais, além do incentivo ao empreendedorismo entre os moradores do Morro. Entretanto, o boom turístico que se presenciou com o início do programa não conseguiu resistir aos problemas já bastante conhecidos e recorrentes naquele local: a diminuição progressiva de investimentos do Estado nos projetos ali implementados, a falta de novos projetos e a violência crescente decorrente de disputas pelo domínio do território pelo tráfico de drogas, consequência do enfraquecimento da UPP.

\title{
A QUESTÃO DA PESQUISA E SUA RELEVÂNCIA
}

O intuito da pesquisa foi identificar a dinâmica do desenvolvimento do turismo na favela Santa Marta após a implementação da Unidade de Polícia Pacificadora e da consequente criação do Programa Rio Top Tour, articulando este processo com os reflexos na comunidade em questão, principalmente após os recorrentes episódios de violência que evidenciam a ineficácia desta. A metodologia utilizada 
procurou atender os objetivos propostos através de incursões pela favela, observação de campo e obtenção de relatos de moradores e turistas, além de reflexões teóricas, investigações bibliográficas e documentais.

A geografia crítica permite compreender a estratégia do capitalismo de absorver os espaços através de várias formas e, dentre elas, o turismo. Na perspectiva de contemplar as determinações históricas, espaciais, políticas e econômicas que o direcionam, a presente proposta visa construir um objeto de pesquisa a partir de questões socialmente pertinentes e cientificamente relevantes para a Geografia, bem como traçar propostas alternativas a partir das contradições levantadas.

O turismo geralmente é apresentado como uma atividade capaz de inserir localidades na lógica mercadológica, de forma a permitir o desenvolvimento das mesmas. Assim, diversos planos e programas são pensados e lançados, fomentados pelo idealismo do crescimento econômico. Sem o entendimento dos processos que conformam o espaço mediado pelas relações sociais de produção, tais pospostas acabam acentuando contradições e perpetuando desigualdades.

Levantá-las e apontá-las, portanto, pode contribuir com: 1) a leitura da realidade para além da sua forma aparente, revelando a essência das questões e podendo operar mudanças na consciência coletiva frente à realidade criada com vistas ao desenvolvimento da atividade turística; 2) o combate ao processo de espetacularização dos espaços e seus elementos, sejam eles tangíveis ou intangíveis; 3) questionamentos quanto à potencialização ou amenização de contradições por meio da atuação do turismo.

A construção da favela como mercadoria em prol da expansão do capital envolve uma série de medidas que, com o intuito de impulsionar a atividade turística, acabam por reproduzir em tais espaços as contradições das relações sociespaciais de produção, trazendo uma falsa noção de desenvolvimento já que o turismo, nesta estrutura, pode se configurar como uma atividade catalisadora de diversas formas de desigualdade. A adoção de medidas invasivas visando a retomada do controle do território através das Unidades de Polícia Pacificadora (UPPs) abriu caminhos para a institucionalização do turismo na favela Santa Marta e para o desenvolvimento do turismo de base comunitária no local. Entretanto, a implementação de um Estado punitivo em detrimento ao Estado de direito promove uma política de pacificação inconstante e superficial. Assim, este trabalho evidencia também o colapso decorrente da fragilidade das UPPS e seu impacto no fluxo turístico dentro das favelas afetadas, causando intenso processo de decadência da atividade, e consequentemente, acarretando numa nova forma de reorganização do espaço.

A presente pesquisa capta uma conjuntura específica da cidade do Rio de Janeiro e assim ajuda a compreender aspectos como as utopias do projeto olímpico e seu naufrágio posterior: suas distopias (Mascarenhas, 2014b). Tentamos desvelar o delicado equilíbrio de forças que sustentam a prática do "favela tour", suas fragilidades e contradições diversas.

\section{O TURISMO E A RESSIGNIFICAÇÃO DO ESPAÇO}

A evolução da atividade turística, bem como o processo de absorção da mesma pela lógica do capital, é composta por diversos elementos e tem seu desenvolvimento atrelado às transformações das relações sociais de produção. Por se tratar de um processo de produção de mais-valor, o turismo está intimamente relacionado ao trabalho - tanto no sentido de produzir excedentes, quanto na dicotomia entre trabalho e tempo livre. Em relação ao conceito de tempo livre, esclarece Marx:

[...] a poupança do tempo de trabalho é equivalente ao aumento do tempo livre [...]. O tempo livre, que é tanto tempo de ócio quanto tempo para atividades mais elevadas, naturalmente transformou seu possuidor em outro sujeito, e é inclusive como este outro sujeito que então ele ingressa no processo de produção imediato (MARX, 2011, p. 593-594). Como fenômeno moderno e centrado nas relações de trabalho, a atividade passa a ter como essência o consumo do tempo livre que, por sua vez, desponta como necessidade. Nesse sentido, esclarece Martoni (2014, p. 83):

Sabe-se que o trabalho exige descanso, sendo essa uma necessidade biológica de qualquer animal e, se toda formação social (escravista, capitalista) depende do trabalho concreto dos seus membros, ela também precisa que esses possam suprir outras carências naturais e o tempo livre é uma delas.

Para Rodrigues (1989) "o ócio significa não fazer nada, enquanto que o lazer supõe o consumo do tempo com alguma atividade, que criou a necessidade do consumo do tempo livre". O turismo, ao mesmo tempo, estimula lazer para os que consomem e trabalho para os que permitem que essa 
prática aconteça, ou seja, surge como forma de valorização do "não trabalho" e como forma de consumo do tempo livre. A mesma prática, por outro lado, exige atividade de trabalho, posto que sem essa nada acontece. Entender o processo de desenvolvimento do trabalho torna-se fundamental para entender a própria atividade turística, que acontece, principalmente, como fruto da motivação e do desejo humano. Assim, elucida Luckács (1978, p. 12-13):

Em primeiro lugar, há uma tendência constante no sentido de diminuir o tempo de trabalho socialmente necessário à reprodução dos homens. Trata-se de uma tendência geral, que hoje já ninguém contesta [...] Em segundo lugar, esse processo de reprodução tornou-se cada vez mais nitidamente social [...] Em terceiro lugar, o desenvolvimento econômico cria ligações quantitativas e qualitativas cada vez mais intensas entre as sociedades singulares originariamente pequenas e autónomas, as quais no início - de modo objetivo e real- compunham o gênero humano.

O trabalho voltado à produção de mais valor, apontado como necessidade no mundo moderno, demanda tempo de descanso. Para clarificar, Filho (2004) afirma que "nesse processo, o ócio, o lazer e o turismo aparecem concomitantes à categoria trabalho e à luta contra a opressão e o tipo de trabalho escravo que a população nos séculos XVIII e XIX está submetida. Ou seja, a conquista do não-trabalho aparece intrinsecamente relacionada às reivindicações trabalhistas. Ainda nesse sentido, esclarece Rodrigues (2011, p. 1):

\begin{abstract}
A diminuição da jornada de trabalho - diária, semanal e anual - aliada a outras conquistas sociais da classe trabalhadora ampliaram sobremaneira o tempo livre, o que refletiu diretamente na multiplicação e diversificação das atividades de recreação e, por extensão, do turismo de massa. As razões dessa expansão são complexas e derivam de fatores que atuam não de forma linear, mas de maneira interativa no processo global, situando-se nos campos econômico, social, psicológico, político, cultural, ideológico, além de outros.
\end{abstract}

Dessa forma, o turismo firma-se como força produtiva ao abarcar práticas sociais como via ou instrumento para a produção de mercadorias, não sendo inteligível sem as devidas conexões com as relações socioprodutivas estabelecidas no processo de absorção dos valores de uso em conversão em valores de troca.

Ao analisar a atividade turística a partir da perspectiva de um fenômeno da modernidade, isto é, da expansão e do aprofundamento das relações sociais de produção, pode-se considerar que a intensificação e a mercantilização das atividades turísticas estão diretamente atreladas ao processo vital do capital, ou seja, a sua valorização. Quando submetido à lógica do mercado e das relações produtivas mais desenvolvidas, o turismo deve, por obrigatoriedade, adotar um caráter expansivo para sua sobrevivência enquanto produtor de valor (mercadoria) e, sobretudo, de valor-capital em espaços, culturas e tradições com apelos essenciais à essa relação social.

Como fenômeno econômico e cultural, o turismo também produz, reproduz e re-significa os espaços. A ideia de transformar a cidade em vitrine, através da espetacularização e da produção de megaeventos que negligenciam determinados espaços em detrimento de outros, demonstra como se dá a atuação do turismo enquanto atividade subordinada ao grande capital. A transformação da cidade do Rio de Janeiro para a produção da Cidade Olímpica, por exemplo, impactou de forma significativa a determinadas localidades através de revitalizações/desapropriações e da criação de novas centralidades, como avalia Mascarenhas (2016b, p. 11):

\begin{abstract}
Além de acelerar o avanço do setor imobiliário e de toda uma concepção urbanística já superada, baseada no automóvel particular, a opção pela Barra da Tijuca como "coração dos Jogos" favoreceu grandes agentes privados atuantes no local e promoveu intensa degradação ambiental, com destaque para o campo de golfe. Além de todos esses impactos, esse processo tem outros agravantes. Por um lado, a política de transporte intrametropolitano, considerada pelo discurso oficial um dos principais legados dos Jogos, concentrou todo o planejamento em torno da Barra da Tijuca, como suposta "nova centralidade" da cidade.
\end{abstract}

A transformação de determinado lugar em "produto turístico", a depender de suas vantagens de localização, pode alterar drasticamente as relações ali contidas. O lugar ganha nova valorização, as relações sociais de produção se modificam e a cultura se transforma em potencial atrativo. Desta forma, padroniza-se o comportamento e as tradições, gerando a espetacularização dos eventos e a pasteurização da cultura, que nesse contexto figura como elemento diretamente relacionado à produção do espaço, posto que também é fruto das relações sociais que permeiam e permitem essa 
produção. É nesse contexto que processos de hierarquização do espaço são viabilizados, tais como a higienização e gentrificação. Por conseguinte, elucida Rodrigues (1991, p 77):

A dificuldade para definir o espaço turístico está basicamente em captar o peso ou a força que esta atividade exerce na produção do espaço. Distinguem-se facilmente os espaços de vocação turística, como os parques nacionais, onde apesar do turismo ser uma atividade intensamente explorada, não foi esta que os produziram. Por outro lado encontram-se espaços produzidos pelo turismo e para o turismo, apesar da ausência de quase todos os fatores apontados como favoráveis para a produção do espaço turístico.

Segundo Arantes (2000), a cultura e/ou os costumes e tradições transformaram-se em estratégia de desenvolvimento a partir dos anos 1980 e configuram como instrumento das práticas mercadológicas:

À medida que a cultura passava a ser o principal negócio das cidades em vias de gentrificação, ficava cada vez mais evidente para os agentes envolvidos na operação que era ela, a cultura, um dos mais poderosos meios de controle urbano no atual momento de reestruturação da dominação mundial (ARANTES, 2000, p. 33).

Essa conversão da cultura em moeda de troca pode ser percebida, segundo Arantes (2000), através das estratégias adotadas com o intuito de revitalizar determinados espaços e/ou torná-los economicamente atraentes. Essa dinâmica se realiza através de políticas culturais que transformem a cidade em espetáculo, estimulando a ideia de progresso e de pertencimento, naturalizando os conflitos existentes e agravados através de tais práticas. Essa ideia de progresso associado à atividade turística é reforçada por alguns autores, tal como Beni (1999, p. 97), o qual avalia que "em vista de seus importantes efeitos econômicos, sociais, ambientais, políticos e culturais, o turismo, organizado e planejado, é poderoso instrumento de aceleração ou complementação do processo de desenvolvimento". Com essa afirmação, o autor acaba por apresentar o turismo como uma alternativa viável para que comunidades portadoras de vantagens comparativas sejam inseridas na lógica reprodutivista do valor a mais. Esse processo se dá de forma direta e indireta com a reconfiguração das atividades do produtor direto para fins das novas dinâmicas produtivas que alcançam e transformam os espaços.

A questão essencial a ser ressaltada é que não haveria problema algum com a expansão da produção social de serviços em um dado espaço, se esses fossem postos como valores de uso. Entretanto, esse desenvolvimento se dá por uma hierarquização socioprodutiva, voltada para a troca, que define os atores que produzem e aqueles que ficam com os resultados da produção, marcando as desigualdades "no e do" espaço diante da impossibilidade de os sujeitos desenvolverem suas diferenças de forma igualitária. A criação de novas geografias e a formatação do espaço, inerentes à qualquer atividade através da qual se pretenda alcançar a hegemonia dos territórios, implica em perigos potenciais decorrentes do agravamento das desigualdades. Dessa forma, é possível concluir que o espaço é dominado pela racionalidade - forma burguesa das trocas - e que a ação humana é responsável pela criação de novos espaços geográficos, posto que o capital sobrevive da expansão. No entanto, esse processo de expansão encontra limites a partir das próprias contradições que produz, resultando numa lenta e constante destruição e recriação dos espaços (HARVEY, 2011).

Ajustada às implicações da globalização, a atividade turística não admite uma estrutura passível de harmonização. Como proporcionar benefícios sociais e econômicos aos espaços turísticos, a partir da compreensão sistêmica e econômica do turismo diante da globalização, trabalho e acumulação cada vez mais flexíveis e desiguais?

A medida em que o turismo atua como meio para competir na economia globalizada, mais se permite desenvolvê-lo como uma atividade para instauração e expansão dos valores e estratégias da lógica dominante. Assim, quanto mais se defende sua orientação econômica globalizada, mais difícil se torna compreendê-lo como um fenômeno social de encontro, seja para pensar uma forma de atuação menos reducionista - considerando a complexidade do fenômeno turístico, seja com o intuito de reconhecer suas contradições e conflitos.

A atividade turística situada nos limites da forma material da vida social dominante atua como produto e reprodutora de uma mesma lógica, que são as relações sociais estabelecidas com o fim da concretização do mais-valor Por isso, aos espaços interessantes à transformação do dinheiro em capital, a expansão do turismo (em suas diversas tipologias estabelecidas pelo mercado) firma-se como instrumento necessário para a lógica reprodutivista do capital, alavancando, para a sua própria vitalidade, outras formas de mercantilização do espaço. 


\title{
MEGAEVENTOS E TURISMO: A CIDADE ESPETÁCULO
}

A transformação da cidade em cidade-espetáculo promovida pelo acolhimento de eventos como a Copa do Mundo e os Jogos Olímpicos de 2016 também reafirmam a vocação turística do Rio de Janeiro (URANI, 2009). A cidade enquanto espetáculo, de acordo com Debord (1997), perpassa pela valorização da imagem desta a partir de modelos internacionalmente aceitos. Ao projetar a cidade num cenário mundial competitivo, ela é transformada uma "marca" internacional, reconhecendo, promovendo e valorizando seu potencial de realização de negócios com o intuito de atrair investidores e turistas. Segundo Mascarenhas (2014a, p. 62):

\begin{abstract}
Ao estudar e propor a noção de urbanização turística, Mullins (1991) já chamava a atenção para a formação de enclaves, como "redutos espaciais de consumo hedonista". Nestes espaços de realização dos desejos, o bem-estar do turista não pode ser molestado pela presença de personagens e usos alheios à fantasia do consumo. Portanto, todas as experiências aqui descritas, mesmo quando bemsucedidas do ponto de vista do afluxo de visitantes, quase sempre não escapam a um modelo segregador, que acaba reforçando e refletindo a produção mais geral do espaço urbano contemporâneo, quando no marco do neoliberalismo e do empreendedorismo.
\end{abstract}

Debord (1997) afirma ainda que o espetáculo não se configura como mero conjunto de imagens, mas se desenvolve como um conjunto de relações mediadas por imagens. A produção do espetáculo diz respeito, sobretudo, à mercantilização do que foi vivido, da memória - o sujeito deixa de atuar e de se apropriar das vivências para tornar-se expectador. Cabe dizer ainda que nesse processo a lógica de mercado monopoliza o comportamento, a imagem, a vivência:

O espetáculo decorreria do fato de que o homem moderno ser demasiado
expectador [...] que os próprios homens, na realidade maciça da atual vida social,
não vivem acontecimentos. É porque a própria história persegue a sociedade
moderna como um espectro, que se encontra a pseudo-história construída a todos
os níveis do consumo da vida, para preservar o equilíbrio ameaçado do atual tempo
congelado (DEBORD, 1997, p. 130).

As formas de sociabilidade propiciadas e produzidas pela sociedade do espetáculo não escapam à lógica da mercadoria: ao contrário disso, criam novas possibilidades de perpetuá-la. No caso dos megaeventos esportivos, o esporte - poderosa ferramenta de transformação social - é transformado em objeto para a troca com a finalidade de manter o funcionamento da sociedade dentro da lógica do mercado. Assim, multiplicam-se as políticas de city marketing com o intuito de ressignificar o imaginário relacionado às cidades em uma escala mundial, norteando as intervenções urbanas que reforçam a cidade enquanto empresa, como reforça Mascarenhas (2014a, p. 56):

Sociedade do espetáculo, do simulacro, das representações. Neste quadro de valorização do simulacro, emergem as retóricas competitivas expressas no city marketing. E, entre as estratégias de city marketing se insere a promoção de grandes eventos esportivos [...]como estes se beneficiam do modelo vigente de espetacularização urbano, bem como este modelo, que tem o empreendedorismo como fundamento, se beneficia dos megaeventos para conquistar visibilidade mundial e produzir seus espaços monumentais de consumo.

A cidade espetáculo também reforça a hegemonia do Estado (MASCARENHAS, 2014a) que, entre ressignificações, intervenções e obras megalomaníacas, promove uma realidade inventada que em nada se parece com a vida cotidiana - tais obras são imbuídas de significados que reforçam a sensação de ordem e de controle. No Rio de Janeiro, a necessidade de reforçar a imagem da cidade maravilhosa no âmbito internacional passa fundamentalmente pela questão da segurança - daí, por exemplo, o empenho no desenvolvimento de um projeto de pacificação (ou militarização) das favelas com a implementação das UPP's - medida diretamente relacionada ao crescimento do fluxo turístico na cidade.

As políticas voltadas à espetacularização e a reconfiguração do território a partir do turismo acabam por reforçar a formação de enclaves urbanos fortificados (CALDEIRA 1997) que resultam no rompimento das relações horizontais entre os lugares e onde é possível controlar não apenas o acesso a esses espaços, mas também o comportamento dos indivíduos ali inseridos e suas tradições, de forma a atender ao fetiche do turista - ainda que isso signifique negligenciar os problemas existentes e subjugar a população que não se encaixa nesse simulacro, fomentando desigualdades. 


\title{
FAVELA TOUR: UTOPIAS E DISTOPIAS EM FACE DA COMPLEXIDADE
}

O Turismo de realidade (reality tour) é o nome que se dá à prática de vivenciar condições reais (tais como miséria, perigo e dificuldades) de forma "autêntica". Ocorre em diversas partes do mundo: de vilarejos na Índia até simulações de favela em hotéis de luxo na África do Sul (Figuras 5 e 6) qualquer lugar onde exista uma condição a ser explorada. Segundo Freire-Medeiros (2009, p. 29):

\begin{abstract}
A curiosidade de saber e de ver como vivem os pobres não constitui novidade. Como demonstra o historiador Seth Koven (2004), a elite vitoriana fez da experiência em primeira mão entre os indigentes algo essencial aos que aspiravam falar com autoridade acerca das questões sociais da época. Assim, todos os cidadãos que simpatizavam com os pobres [...] sentiam-se obrigados a visitar, ou mesmo viver e trabalhar, em bairros degradados de Londres, como Whitechapel e Shoreditch. Era o que à época se chamava de slumming. Em 1884, o Dicionário Oxford definiu o termo como a tendência a visitar as áreas mais pobres de diferentes cidades, seja com o propósito de fazer filantropia seja apenas por curiosidade.
\end{abstract}

Com pitadas de sadismo, o slumming praticado pela elite vitoriana no século XIX já transformava cenários de pobreza em entretenimento. A prática "saiu de moda" só no século seguinte, entretanto, voltou no século XXI, com outro formato, mas com objetivo semelhante - desta vez disfarçada de filantropia e caridade e impulsionada pela força da mídia, que será abordada posteriormente no presente trabalho. Como esclarece Freire-Medeiros (2009, p. 32):

A prática do slumming retorna, por assim dizer, não como uma resposta às insuficiências do mercado, que deveriam ser "consertadas" pelos sujeitos caridosos, mas como parte constituinte desse mercado, que define um valor monetário para a pobreza, um preço devidamente acordado entre agentes e consumidores. Mas que mercado é este que permite que até a pobreza seja empacotada como mercadoria turística?

Embora seja difícil estabelecer com precisão as motivações que impulsionam a prática, é possível afirmar que o desejo de vivenciar uma realidade diferente daquela à qual o turista está habituado é uma delas - porém, por tempo limitado e sem correr os riscos que aquele cotidiano pode oferecer. De acordo com Bauman (1999) o capítulo "Turistas e Vagabundos" apresenta a percepção do turista e do vagabundo como forma de ilustrar as relações de poder dentro da lógica capitalista.

Os turistas, sem localidade fixa, podem circular livremente: não reconhecem os espaços porque estão em todos os lugares - são globalizados, exercem poder sobre os locais. Os vagabundos, por sua vez, são locais e vivem numa espécie de confinamento: surgem como o alter ego do turista, movimentamse por necessidade e para atender às demandas do turista:

Os turistas ficam ou se vão a seu bel-prazer. Deixam um lugar quando novas oportunidades ainda não experimentadas acenam de outra parte. Os vagabundos sabem que não ficarão muito tempo num lugar, por mais que o desejem, pois provavelmente em nenhum lugar onde pousem serão bem-recebidos. Os turistas se movem porque acham o mundo a seu alcance (global) irresistivelmente atraente. Os vagabundos se movem porque acham 0 mundo a seu alcance (local) insuportavelmente inóspito. Os turistas viajam porque querem; os vagabundos porque não têm outra opção suportável (BAUMAN, 1998, p. 101).

No slumming, a lógica do "Turista e o Vagabundo" é intensificada: a condição do vagabundo que antes permitia que fetiche do turista fosse atendido, se transforma em objeto desse fetiche. $\mathrm{E}$ se antes a ideia de movimento como necessidade de fuga já era difícil para o vagabundo, agora ela é ainda mais inacessível: da falta de mobilidade à dificuldade em conseguir um visto, por exemplo. $O$ vagabundo é cada vez mais refém do local e o turista cada vez mais refém do consumo. O interesse acerca da favela e a exposição midiática sobre o seu cotidiano não são recentes (BOTTINO, 2016), conforme reportagem (Figura 1) datada de 18 de maio de 1926 do jornal O Globo relatando a visita do poeta italiano Marinetti ao morro da Favella (atual Morro da Providência). 
Figura 1 - Visita à favela retratada na primeira página de jornal carioca, 1926.



Fonte - Acervo O Globo.

Nas décadas seguintes, além da expansão das favelas, a exploração midiática contribui com a construção de uma imagem estilizada da favela como local de autenticidades, repleto de simbologias. As relações sociais ali contidas, o vestuário, as comidas, o cotidiano festivo e, ao mesmo tempo, violento logo culminaram na criação de uma trademark da favela:

\begin{abstract}
Minha hipótese é que, para responder estas questões, é preciso inserir o processo de construção da favela como destino turístico em um duplo contexto: na conjuntura de expansão dos chamados reality tours mundo afora; e no fenômeno de circulação e consumo, em nível global, da favela como trademark, como um signo a que estão associados significados ambivalentes que a colocam, a um só tempo, como território violento e local de autenticidades preservadas (FREIRE-MEDEIROS 2006, p. 2).
\end{abstract}

A Conferência das Nações Unidas sobre o Meio Ambiente e o Desenvolvimento, conhecida como ECO-92, realizada em junho de 1992 na cidade do Rio de Janeiro, tinha o objetivo de debater os problemas ambientais mundiais. Ela foi determinante para a consolidação da favela como destino turístico no Rio de Janeiro. Segundo Valladares (2005, p. 202), exatamente em 1992 acontece o início do turismo na favela, com a entrada da Rocinha entre as metas dos tours da cidade. Consolidada como produto turístico, começa então a disputa pelo território das favelas por parte das agências receptivas, com destaque para Favela Tour, Exotic Tour e Jeep Tour. Cada agência tem especificidades no que diz respeito ao produto ofertado: os roteiros são semelhantes, mas a forma de realizá-los é o diferencial entre elas. É importante destacar também que a maior parte dos passeios turísticos se concentram nas favelas da zona sul, seja pelas paisagens, pelo contraste social bastante acentuado nessa região da cidade ou pela sensação de que existe mais segurança nessa região. Assim, explica Freire-Medeiros (2006, p. 21):

Mas, o fato é que a potencialização do turismo será opção exequível apenas para algumas favelas. Por tudo que foi dito aqui, é difícil imaginar que conquistem algum valor no mercado turístico aquelas que estão longe da Zona Sul e que não têm "apelo estético" e consonância com os critérios pré-estabelecidos pelos promotores.

O turismo nas favelas acaba por reforçar a polarização e surge como exemplo vívido da expansão do capital ao comercializar a condição humana atrelada à pobreza. Resulta numa visão distorcida da 
realidade que acaba por ocultar sua materialidade e, a partir do que Harvey (2005) chama de "utopia do livre mercado", termina naturalizando a desigualdade ao promover a ideia de um ambiente fantasioso, espetacularizado, produzido. É nesse contexto que se dá a turistificação da favela como espaço exótico, de alteridade marcante e curiosa. Também verificamos processos de hierarquização do espaço engendrados em meio a processos de higienização e gentrificação. Essas políticas de enobrecimento produzem novas centralidades e negligenciam determinados espaços - aqueles que não são absorvidos diretamente pelo capital. A movimentação turística e a ocupação do morro por estrangeiros e pela classe média podem acabar por expulsar os moradores do local. As festas, eventos e comercios funcionam por e para os visitantes; encarecendo o custo de vida local e obrigando os moradores em situação de maior vulnerabilidade a procurarem outros locais.

O consumo e transformação do espaço ocasionados através da absorção do mesmo pelo capital e perpetuados através da atividade turística têm características peculiares, pois, como afirma Harvey (2005, p. 28), "não se comercializa a terra, o recurso natural ou o local de qualidade singular, mas a mercadoria ou serviço produzido por meio de seu uso". Posto que a atividade turística se trata de um processo que reproduz a lógica do capital, as desigualdades e a segregação que permeiam essa lógica também são reproduzidas - o turismo, como afirma Moesch (2000, p. 9), "[...] se desenvolveu com o capitalismo. A cada avanço capitalista, há um avanço do turismo". Esse desenvolvimento desigual dos lugares, gerando a supervalorização de uns e marginalização de outros, cria o que Santos (2006) denomina como "guerra dos lugares". Cria-se o espaço do turista, o espaço do habitante que pertence à elite, o espaço do marginalizado e assim se concretiza a segregação. É nesse sentido que se caracteriza a transformação do espaço constituído pelas favelas em produto de consumo. Atendendo às exigências mercadológicas, o que deveria ser considerado uma condição e consequência da lógica do capital (nesse caso, a pobreza), transforma-se em agente reprodutor do mesmo - o que acaba por naturalizar tais condições.

\section{A TURISTIFICAÇÃO DA FAVELA SANTA MARTA}

Localizada no Morro Dona Marta, em Botafogo - bairro nobre da zona sul do Rio de Janeiro - a favela Santa Marta tem seu início datado na primeira metade do século XX. Segundo o historiador Milton Teixeira, citado por Cunha e Mello (2011, p.378), a área pertencia aos padres jesuítas que permitiram que operários contratados para trabalhar nas obras do Colégio Santo Inácio ali sem instalassem em meados de 1924. Em 1929, com a crise cafeeira, muitos imigrantes oriundos do Vale do Paraíba concentraram-se na região em busca de ofertas de trabalho. O local sobreviveu aos ataques promovidos pela política de remoção promovida pelo governador Carlos Lacerda, entre 1960 e 1965, graças à luta dos moradores e ao apoio de Dom Helder Câmara que, contrário à expulsão dos seus moradores, organizou mutirões comunitários para a construção de caixas d'água no alto do morro, bem como a instalação de caixas de força para o bombeamento da água (Barcellos, 2008, p. 70). Atualmente, com cerca de $54 \mathrm{~km}^{2}$ e, aproximadamente, 4.000 habitantes a favela é pequena se comparada às demais da zona sul. $\mathrm{O}$ acesso ao morro pode ser feito por Laranjeiras ou por Botafogo, pelas ruas Marechal Francisco de Moura - que dá acesso à escadaria - ou Jupira, que dá acesso à Praça do Cantão. Segundo Cunha \& Mello $(2011$, p. 379) "era nessa praça que os traficantes costumavam ficar exibindo armas e munições antes da chegada da UPP, sendo o lugar às vezes também chamado de antiga boca". O plano inclinado, apelidado de "bondinho", foi instalado em 29 de maio de 2008 e, apesar de facilitar o acesso ao topo da favela, teve como consequência a remoção de alguns moradores que habitavam no seu percurso. 
Figura 2 - Mapa da favela Santa Marta.

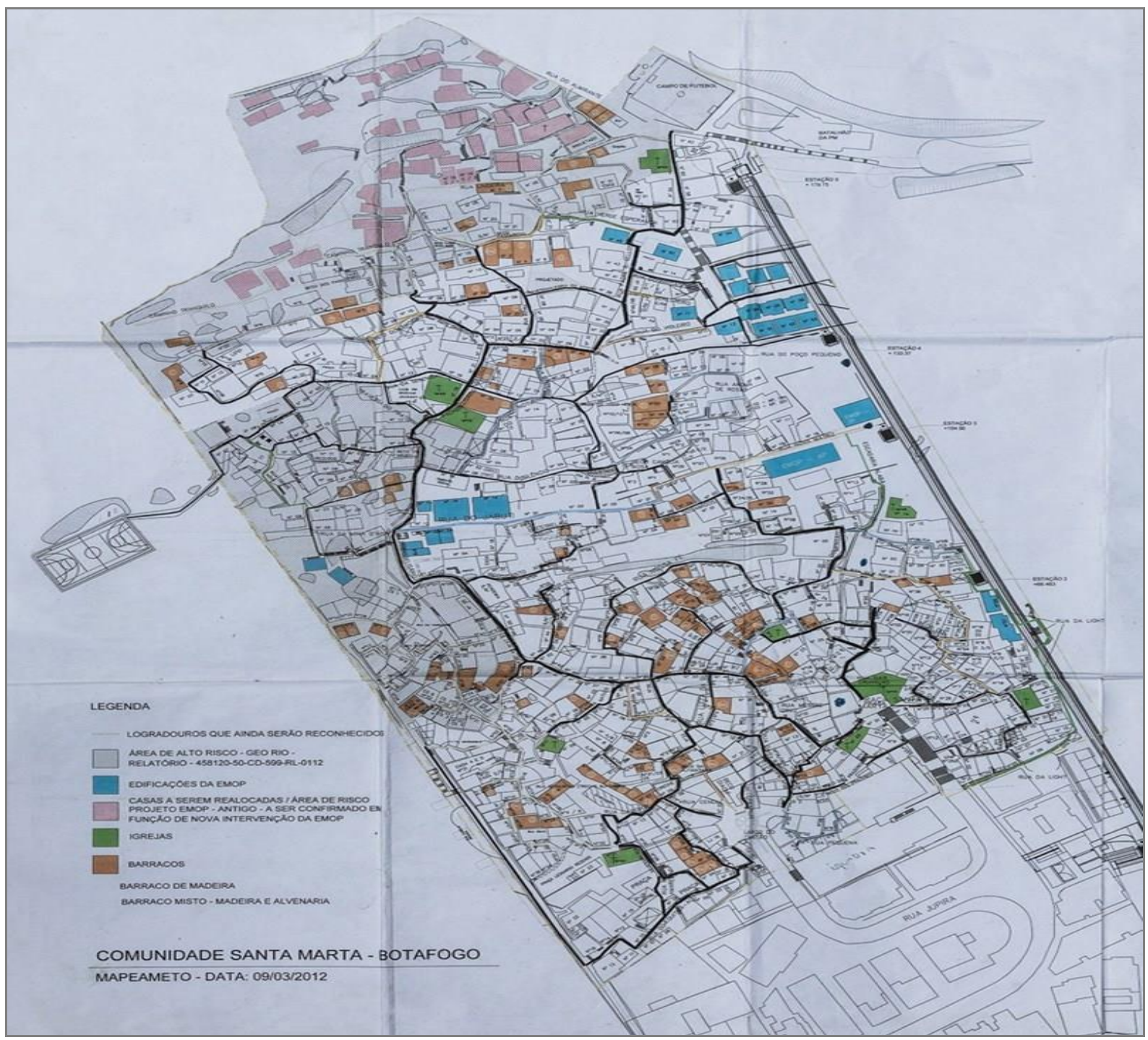

Fonte - Co-creation Network.

Entre os anos 1980 e 1990, o morro Santa Marta é constantemente noticiado devido aos conflitos envolvendo diferentes facções que disputavam o domínio do território e o monopólio da venda de drogas - sobretudo o Comando Vermelho e as facções rivais. Também devido à polícia carioca, que realizava constantemente incursões militarizadas no morro (Barcellos, 2008). Contudo, em 1996 o Morro Dona Marta ganha outro tipo de visibilidade quando é escolhida como cenário do videoclipe "They don't care about us", do popstar norte-americano Michael Jackson. A gravação levanta rumores sobre uma possível negociação que os produtores teriam feito com o chefe do tráfico local, Marcinho VP (Barcellos, 2008). A questão da exploração da pobreza e estereotipização da favela foi levantada pela mídia e pelas autoridades da época. Ao ser questionado, o diretor Spike Lee afirmou: "O que eles acham? Que a pobreza no Brasil é segredo?" (FREIRE-MEDEIROS, 2009, p.19). A repercussão foi tão grande que levou à transformação do local de gravação em espaço temático do artista que viria a se tornar, posteriormente, um dos principais pontos turísticos ganhando, inclusive, uma estátua de bronze do cantor. 
Figura 3 - Estátua do cantor Michael Jackson localizada no Morro Santa Marta.

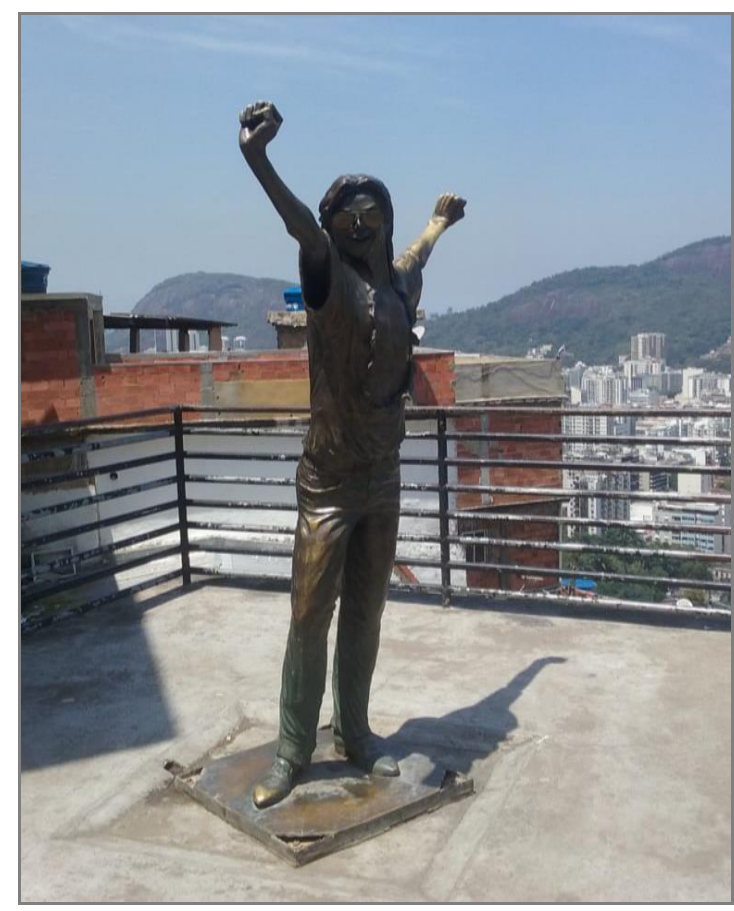

Fonte - arquivo da autora, 2018.

Dentre os demais equipamentos turísticos, destacam-se a Praça Cantão (palco do projeto Favela Painting, parceria entre os artistas holandeses Haas e Hahn e a Tintas Coral), o mirante do Pedrão e o mirante Santa Marta. O trajeto pode ser feito a pé ou através do plano inclinado, que tem cinco estações distribuídas ao longo de seu percurso.

Figura 4 - O plano inclinado, apelidado de "bondinho".

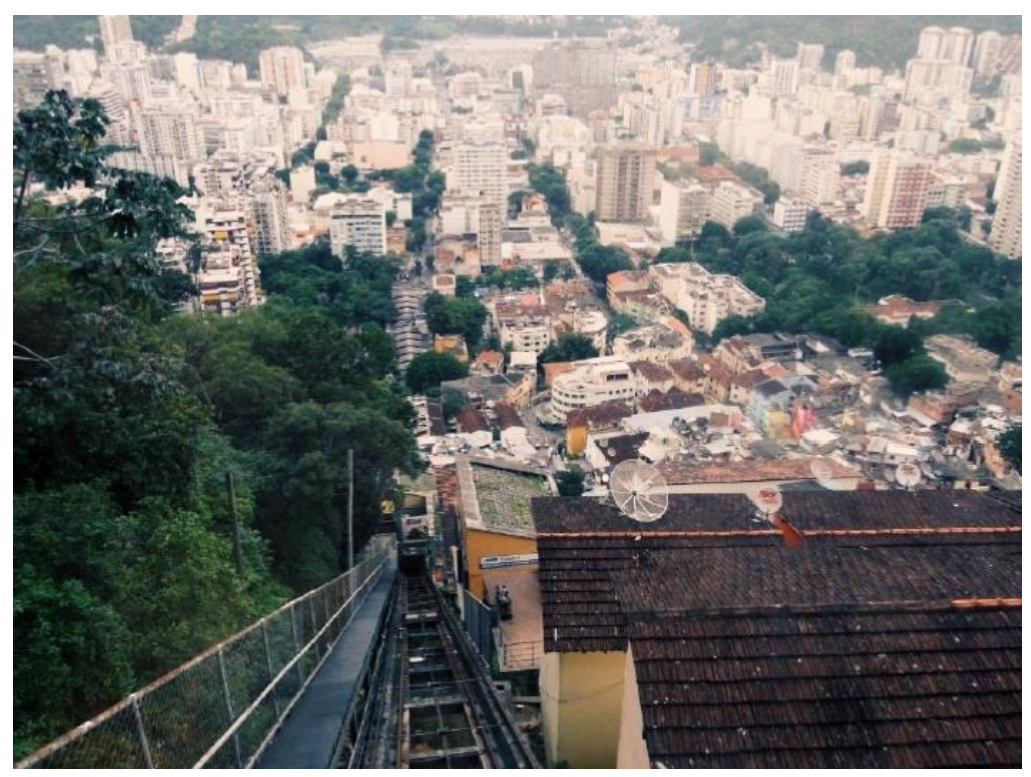

Fonte - arquivo da autora, 2018.

A intensa projeção midiática aliada às singularidades do Morro conferiram ao Santa Marta o polêmico rótulo de "favela modelo" - tal status viria a transformar o local em laboratório para inúmeros projetos governamentais e privados que ressignificaram seu espaço e submeteram a favela a inúmeros processos de transformação - entre eles, a instalação da primeira Unidade de Polícia Pacificadora (UPP) em 19 de Dezembro de 2018. A instalação da UPP consolidou o local como laboratório para a 
implementação de outros projetos sociais visando a reestruturação da favela, principalmente em relação à infraestrutura básica, como esclarece Cunha e Mello (2011, p. 385):

No início de 2009, foi instalada uma rede de internet sem fio gratuita. E, atualmente, já estão regularizados o fornecimento de água, luz e TV por assinatura, afetando sensivelmente a informalidade dos gatos e das "gatonets", práticas até então comuns de acesso respectivamente à energia elétrica e à TV a cabo e geralmente controladas por milícias ou pelo tráfico de drogas. O primeiro serviço a ser regularizado foi o fornecimento de energia elétrica, em meados de 2009.

Entretanto, muitos dos projetos iniciados com o intuito de regulamentar as moradias e os serviços de fornecimento de água e luz não atendiam as demandas locais pois não levavam em consideração as especificidades do lugar. Ainda hoje, dez anos depois da instalação da primeira UPP, a favela ainda sofre com problemas como esgoto a céu aberto e acúmulo de lixo - o que demonstra que as intervenções do Estado foram limitadas e insuficientes. A melhoria e/ou regulamentação dos serviços prestados elevaram drasticamente o custo de vida para a população, que também passou a sofrer com a especulação imobiliária. Ainda assim, a presença da UPP foi bem aceita já que, inicialmente, inibiu o avanço do tráfico de entorpecentes e os confrontos armados envolvendo facções rivais que disputavam o poder sobre aquele território. Vale ressaltar, no entanto, que a atuação da UPP é limitada por se tratar de um instrumento repressor do Estado, não de um instrumento transformador do espaço. Assim, mantidas as condições que permitiram o crescimento e a expansão das organizações criminosas no local, a tendência é que as mesmas encontrem novas formas de se apropriar do território, fazendo com que a pacificação tenha data de validade. Este foi o contexto que favoreceu a turistificação da favela e que também condicionou seu êxito, conforme presenciamos ao enveredar pelo cotidiano do Santa Marta.

A aparente sensação de segurança, o pioneirismo em relação a pacificação, aliado à projeção midiática contribuiu para a consolidação do morro Santa Marta como "Favela Modelo" aumentando sua popularidade. Assim, o movimento turístico que já existia antes da pacificação, se torna institucionalizado quando, em 2010, surge o projeto denominado Rio Top Tour. O objetivo era destacar o Rio de Janeiro sob um novo ponto de vista, fruto de uma parceria entre o Governo do Estado e o Ministério do Turismo. O programa se tratava, segundo Freire-Medeiros; Vilarouca; Menezes (2016, p. 573), de um "pacote que os agentes públicos idealizaram para embalar o produto Santa Marta e entregá-lo ao mercado turístico".

Além de propor a capacitação de moradores e comerciantes através de um curso técnico em Turismo com duração de dois anos, o Rio Top Tour também contava com um programa de microcrédito que oferecia financiamento de até $R \$ 6.000,00$ por negócio, facilitado por uma agência de fomento da Prefeitura (a Investe Rio). Em relação aos equipamentos, o programa promoveu a implantação de sinalização bilíngue e de placas informativas espalhadas pela comunidade, além da instalação de um quiosque de informações onde o turista poderia contar com as orientações de estagiários bilíngues. $\mathrm{O}$ boom turístico que se deu após a implementação do Rio Top Tour trouxe impactos significativos, como destacam Freire-Medeiros; Vilarouca; Menezes (2016, p. 576):

Ainda que o caráter pouco democrático do Rio Top Tour tenha gerado insatisfações, o fato é que, a partir de sua implementação, a rotina de todos os envolvidos seria irreversivelmente alterada: os promotores de turismo das operadoras privadas, que antes atuavam em outras favelas, tiveram de se adaptar à realidade do Santa Marta; alguns moradores tiveram de calçar os sapatos de guias e empreendedores turísticos; outro tanto se viu ocupando o papel, no mais das vezes, pouco confortável, de atração turística.

O período pós-pacificação aliado ao aumento da circulação de turistas tornou o local atrativo para empresas que, até então, só poderiam ser encontradas fora dali. Em 2011 uma agência do Bradesco foi instalada na Rua Jupira (ANDRADE, 2011, p. 125), dentre outros comércios que passaram a enxergar potencial consumidor na favela. Se por um lado a facilidade de acesso a serviços, antes inimagináveis, e a promoção internacional da favela trazia a sensação de orgulho para parte de seus moradores, por outro, acentuava a especulação imobiliária e o encarecimento do custo de vida, além de tornar alguns espaços inacessíveis. A atividade turística na favela Santa Marta é permeada por singularidades e contradições. Cresceu às custas de políticas públicas invasivas. Atraiu a atenção do setor privado e alterou as formas de controle e gestão do espaço, bem como a relação entre os indivíduos e o lugar através de programas que reforçavam a ideia de pertencimento e do morador como protagonista. 
Em entrevistas concedidas e autorizadas realizadas em Julho de 2018 durante pesquisa de campo, Layos Duarte e Marquinhos, guias turísticos e moradores do morro Santa Marta, afirmam que a favela sempre recebeu muitas visitas - muitas delas motivadas pela exposição midiática - mas, de uma forma mais organizada, só a partir de 2010/2011. Nesse período a atividade passou a crescer vertiginosamente, atingindo seu pico entre 2014 e 2016. Ambos frisaram a valorização do solo ao longo dos anos em que a atividade turística estivera em alta: muitos investidores adquiriram e/ou construíram hostels no morro e no seu entorno. Apesar da evidente especulação imobiliária, ambos afirmaram que não conheciam nenhum caso de morador que tenha deixado sua casa por conta da alta dos preços, mas afirmam que o custo de vida varia bastante nas épocas de grande fluxo turístico. Quando questionados a respeito dos proprietários de tais estabelecimento, os entrevistados informaram que boa parte deles vive no Rio de Janeiro, mas nem todos no morro. Ainda segundo os guias, a curiosidade é a razão central da busca dos turistas por passeios como o Favela Tour. O desejo de vivenciar uma realidade diferente e de confirmar (ou não) aquilo que é transmitido pela mídia também é determinante, bem como a ideia de que ali existe uma "cultura genuína", livre de simulacros. Sobre a percepção dos habitantes em relação à atividade, Letícia, moradora do morro Santa Marta, afirma:

Tem mais ponto positivo do que negativo, né? Eu vejo o turismo aqui como forma da gente arrecadar dinheiro pra investir em coisas que o governo não investe. Muita coisa aqui foi melhorada por causa disso. Não é uma coisa que vai salvar a gente, mas já ajuda. Fora que muita gente aqui aproveita pra vender uma coisinha ou outra pros turistas, comida, lembrancinhas. $E$ eu acho muito bom mesmo que eles vejam que nossa vida não é fácil não, que aqui não tem só bandido, tem muita gente batalhadora. Acho que isso muda a imagem que eles lá fora têm da gente e isso é muito bom porque a gente já sofre muito preconceito. $O$ lado ruim é que é uma coisa que não dá pra gente contar porque tem época que tá lotado de visitante e tem época que não tem quase ninguém, principalmente agora que a gente ta vendo o aumento da violência aqui e no Rio de Janeiro como um todo. Aí quem largou trabalho fixo pra viver disso fica como? E também tem uma pessoa ou outra que acha que todo mundo aqui tem que conversar, ser simpático. Acho que eles esquecem que a gente tem uma vida normal, que isso aqui não é de mentira. Outra coisa que eu acho que tem dois lados é o aumento do preço das casas. Valorizou muito durante um período, tinha casa aqui sendo vendida por mais de um milhão. Era ruim pra quem vinha de fora procurando moradia, mas pra muito morador aqui que batalhou pra ter sua casa foi bom. Eu mesma conheço gente que alugou a casa durante umas temporadas e foi morar em outro lugar mais barato pra lucrar com isso. Então acho que tem dois lados da moeda, não dá pra dizer se é uma coisa boa ou ruim. No geral, eu acho que os pontos positivos pesam mais que os negativos (Letícia, 21 anos, estudante).

Já Antônio, também morador do morro, reitera que não gosta da sensação de ser "visitado como bicho". Ele cita o incômodo com a curiosidade dos turistas a respeito do cotidiano dos moradores e com o fato dos turistas fotografarem tudo (nem sempre com permissão): das casas ao lixo acumulado nas vielas.

Figura 5 - Favela Santa Marta.

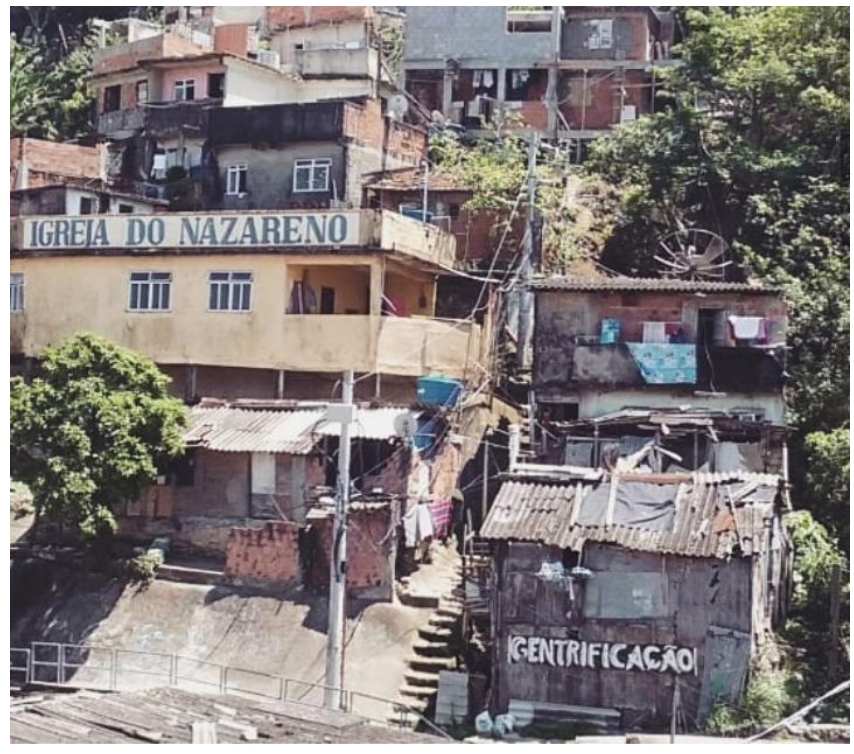

Fonte - arquivo da autora, 2018. 
Se a ideia era enfraquecer estereótipos da favela enquanto lugar de violência, o que se conseguiu foi reforçar a favela enquanto produto, com todas as contradições promovidas pelo fetichismo da mercadoria. Vale ressaltar também que o turismo praticado nessas condições pode gerar competitividade entre as favelas a partir do momento em que classifica algumas como "turisticáveis" e outras não. O conjunto de medidas que tornaram a favela Santa Marta viável para a prática do turismo, no entanto, estavam condicionadas à pacificação. Só seriam possíveis enquanto o local representasse um modelo de sucesso da intervenção do Estado. Ainda que houvesse todo um imaginário acerca do tráfico e o desejo dos turistas em conhecer essa realidade tão difundida pelos instrumentos midiáticos (alguns visitantes relataram, por exemplo, o desejo de chegar a locais onde fosse possível presenciar os jovens armados, como nos filmes), o fluxo de visitantes aumentou consideravelmente no período pós-pacificação. Esse fato demonstra que a segurança (ou aparente segurança) é a ponte entre o turista e a favela. Onde não há minimização da violência, raramente há visitação. Reafirmando as colocações de Bauman em "Turistas e Vagabundos" - o turista busca o simulacro, não os riscos.

\section{ATÉ ONDE PODE O TURISMO: QUEM É O DONO DO MORRO?}

Em meados de 2017 - nove anos após a inauguração da UPP - uma imagem emblemática passa a circular nas redes sociais: a famosa estátua de bronze do Michael Jackson com um fuzil pendurado no pescoço. A emblemática imagem, mais do que impressionar moradores e turistas que passavam pela famosa laje, mandava um recado importante: a UPP, que já vinha perdendo o poder de atuação ali, estava desmoralizada. Em menos de dez anos de atuação nas favelas cariocas, a imagem das UPPs já estava desgastada e a atuação dos PMs nas comunidades mais assustava do que protegia. Em 2015, na Rocinha, o caso Amarildo ganhou repercussão mundial: tratava-se do pedreiro Amarildo Gomes da Silva, que foi abordado pela Polícia Militar e desapareceu em área de UPP. O fato gerou grande comoção, mas, como afirma Franco (2014, p. 106), não foi um caso isolado:

O fato trouxe à tona o nome do pedreiro Amarildo Gomes da Silva. Porém, não é um fato isolado, uma vez que há indícios de uma continuidade nos procedimentos de desaparecimento, típicos da forma de atuar da PM e de como as forças de "pacificação" atuam. Há milhares de casos pelo estado do Rio de Janeiro, de pessoas que desaparecem e não retornam mais ao convívio familiar.

Os casos de desaparecimento aliados a inúmeros relatos denunciando a truculência na ação dos policiais em áreas de UPP já mostrava o retorno do policiamento repressivo, bem distante do modelo de abordagem proposto que tinha como um dos princípios incentivar a aproximação e o bom convívio com a comunidade, como previsto no Decreto $N^{\circ} 42.787$. Quando se fala no declínio do projeto das UPPs se faz necessário lembrar que, além dela, todas as políticas de pacificação implementadas nos mesmos moldes nos anos anteriores tiveram o mesmo destino. As falhas da segurança pública vão para além do despreparo dos policiais, porque esta seria apenas um reflexo de um Estado que fomentou a guerra ao tráfico ao longo dos anos. Assim, é impossível vivenciar a cidadania nesse contexto:

Onde há guerra não pode haver direito. O militar é adestrado para o inimigo, o policial para o cidadão. Na estrutura militar, a obediência integra a legalidade; na policial, a legalidade é condição prévia da obediência. São formações distintas, dirigidas a realidades também distintas. O sistema de responsabilização é também diferente: não há ordens vinculantes para um policial, adstrito a aferir a legalidade de todas elas (num teatro de guerra, iniciativa similar significaria derrota certa) (BATISTA, 2012, p. 52).

O tráfico de drogas, portanto, não acabou, mas foi "desterritorializado". Porém, com o recuo das UPPs, grupos armados voltaram a circular pelas comunidades e ganharam espaço novamente. Os conflitos entre as facções pelo controle do território cresceram vertiginosamente. Vale ressaltar que as favelas da zona Sul do Rio de Janeiro só sentiram tardiamente os efeitos das falhas do processo de pacificação se comparadas às comunidades da zona norte e oeste. Nestas e nas demais localidades não agraciadas pelo turismo, o efeito foi mais abrupto, os conflitos mais intensos e as condições de vida continuaram mais precárias - porém menos noticiados. No Morro Santa Marta os conflitos também se tornaram cada vez mais recorrentes. O primeiro conflito pós-UPP aconteceu em 2015 e foi amplamente noticiado pela mídia, principalmente por se tratar da favela que, até então, era tida como modelo de sucesso do projeto de pacificação. Seria o início de uma série de confrontos, intensificados após os Jogos Olímpicos Rio 2016. 
Figura 6 - Reportagem sobre tiroteio na favela Santa Marta.

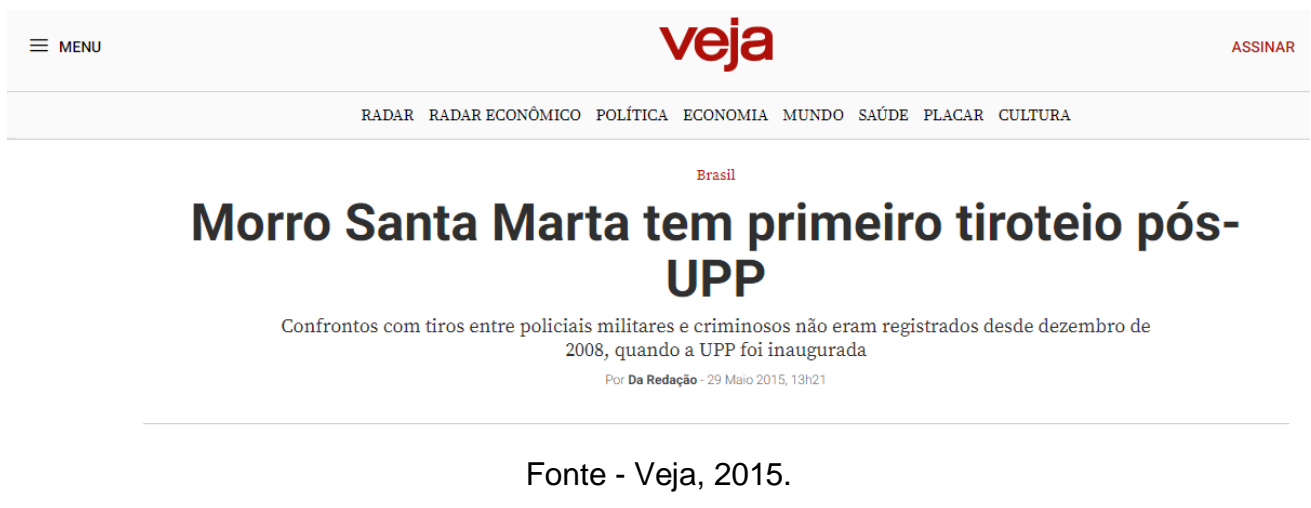

Fortemente influenciada pelo sentimento de insegurança, a movimentação turística acompanhou o declínio das UPPs. Segundo depoimento de Layos Duarte, obtido em 2018, o fluxo de turistas diminuiu consideravelmente por conta do aumento da violência, o que fez com que apenas cerca de 30 a $40 \%$ dos hostels permanecem funcionando - todos os outros faliram. José Hilário dos Santos, presidente da Associação de Moradores do Morro Santa Marta, destaca o impacto do turismo na economia local - muitos moradores trabalhavam direta ou indiretamente no setor - e aponta o aumento dos conflitos armados no local como um dos principais fatores para o declínio da atividade, seguido pela falta de investimentos em programas que fomentem o turismo no local.

As benfeitorias realizadas na favela no período de intensificação do fluxo turístico, sem a manutenção necessária, também vêm se deteriorando: o plano inclinado falha constantemente, os equipamentos que visam facilitar a locomoção no Morro encontram-se degradados, as moradias em situação de risco permanecem na mesma condição e os espaços destinados ao turismo passaram a contar com investimentos mais modestos - o que mostra que o pleno funcionamento da atividade encontra-se atrelado a inúmeros outros fatores. Assim, é possível afirmar que a segurança (ou a aparente segurança) constitui fator determinante para que os passeios aconteçam, indicando uma relação de co-dependência entre turismo e pacificação. Quanto maior o potencial turístico da favela, maior o investimento em políticas de segurança pública. E quanto maior a eficácia destas políticas, maior o fluxo de visitantes.

\section{CONCLUSÃO}

No espaço urbano cada vez mais desigual e excludente, fruto de planejamentos crescentemente alinhados à ideia do empreendedorismo urbano, as favelas despontam como um dos mais emblemáticos sintomas da desagregação social. Com o intuito de retomar o controle sobre esses espaços e adequá-los às exigências mercadológicas vinculadas à realização dos Megaeventos esportivos no Rio de Janeiro, surge a ideia da Polícia Pacificadora. O sucesso inicial da iniciativa permite a institucionalização de uma nova forma de mercantilização da cidade, levando ao "consumo" das favelas através da atividade turística. Esta, enquanto atividade absorvida pelo capital, segue apoderando-se de lugares, culturas e tradições, assim como espetacularizando os eventos e ressignificando os espaços. Desta forma, o turismo descobre na favela uma nova forma de expansão. O processo de mercantilização da favela, nesse contexto, funciona de forma a atribuir valor de troca a esses lugares, de maneira que possam ser comercializados. Assim, a favela é absorvida como matéria-prima da atividade turística, que atua reproduzindo as relações socioespaciais com o objetivo de extrair mais-valor, seja de forma direta ou indireta. Cria-se, nesse contexto, uma espetacularização dos lugares.

A retomada do controle do território do Santa Marta através da implementação da UPP permitiu a institucionalização do Turismo e a efetivação de medidas que melhorassem a infraestrutura no local. No entanto, alguns fatores como a falta de continuidade dos projetos de melhoria implementados pelo Estado, o investimento em uma política de repressão (com policiais despreparados e que não atuam em conjunto com a comunidade), o descontentamento gerado pelo encarecimento do custo de vida no local, decorrente da aparente pacificação e seus desdobramentos, culminaram no agravamento das desigualdades já existentes e no colapso das UPPs, abrindo espaço para o retorno de grupos armados e de confrontos armados. Outro fato a ser destacado é a descontinuidade dos investimentos do Estado no que diz respeito à infraestrutura local. O sucesso inicial das UPPs abriu a possibilidade 
de transformar o Morro em polo turístico através da venda da ideia da "Favela Modelo", atraindo investimentos do setor privado que enxergou no local uma possibilidade de expansão do capital. Porém, a escolha por medidas paliativas em detrimento de ações diretas para a erradicação das condições de miséria encontradas ali acabou por trazer contradições ainda maiores, a exemplo do encarecimento do custo de vida no local e da consequente expulsão de seus moradores.

A sensação de insegurança oriunda do retorno dos confrontos armados perpassa os limites da favela e atinge também os turistas que, apesar de buscarem o turismo de realidade, só o fazem desfrutando de segurança. Destaca-se aqui a urgência da criação e desenvolvimentos de políticas de segurança pública que atuem junto à comunidade, e não contra ela. Vale ressaltar também que medidas que visem alterar o espaço na sua aparência, mas não na sua essencialidade, tendem ao fracasso, ao passo em que desconsideram as especificidades do lugar onde atuam, abrindo espaço para novas formas de controle - seja pelo poder do tráfico, seja pelo poder do capital acentuando as desigualdades.

Em relação à prática da "Favela Tour", constatou-se que a atividade, viabilizada pela intervenção policial do Estado, favoreceu a "culturalização", no sentido proposto por Otilia Arantes (2000), da favela e de seus elementos, de forma a transformá-la em uma trademark ostensivamente explorada por setores públicos e privados com o intuito de encontrar novas formas para a reprodução do capital. Sua comercialização remete ainda a uma falsa noção de desenvolvimento. Ou, pode-se dizer, do desenvolvimento possível nos limites do crescimento econômico capitalista, envolvendo classes e frações de classe. Isso faz com que a subjetividade do indivíduo se sobreponha à materialidade porque a prática produz uma falsa sensação de conhecimento sobre aquela realidade, fazendo com que o turista acredite que a partir desta prática ele pode desmistificar a imagem pejorativa acerca do local e contribuir com o desenvolvimento social do mesmo. Enquanto isso, incentiva nas comunidades um empreendedorismo de fachada, que acaba por reforçar uma competitividade interna, encarecendo produtos e fomentando formas semelhantes à gentrificação; tanto internamente quanto fora delas, quando estimula a competitividade entre as favelas. Constata-se também que, em espaços produzidos por e para o capital, como é o caso da favela turística, a tendência é que exista uma deterioração daquele espaço porque a atuação do capital ali é limitada. $E$, não vendo mais a possibilidade de expansão, encerram-se os investimentos deixando a população à deriva.

A partir do que foi apresentado neste trabalho, faz-se necessária uma profunda reflexão acerca dessas relações, de forma a sair do idealismo para uma realidade construída através das relações sociais concretas, envolvendo necessariamente as mediações das categorias que a formatam sob certas condições sociais e históricas. Somente por meio do conhecimento é possível identificar quais são os processos que permitem a continuidade de uma lógica onde tudo é convertido em produto e onde os valores de uso tornam-se secundários. Essa lógica que, por sobreviver da produção de excedentes e da apropriação dos lugares, acaba por formatar uma sociedade cada vez mais desigual onde a miséria toma novas formas a serem absorvidas pelos processos de reprodução do capital. Como não poderia ser diferente, práticas similares ao Favela Tour, envolvendo a espetacularização da pobreza tornam-se cada vez mais frequentes mundo afora.

\section{AGRADECIMENTOS}

Ao professor Gilmar Mascarenhas de Jesus (in memorian), que permitiu que este trabalho acontecesse.

\section{REFERÊNCIAS}

ARANTES, O. Uma estratégia fatal. A cultura nas novas gestões urbanas. In: ARANTES, O.; VAINER, C.; MARICATO, E. A cidade do pensamento único. Desmanchando consensos. Petrópolis: Editora Vozes, 2000.

BARBOSA, Gabriel Ferreira. A Favela Santa Marta e seus guias de turismo: identidade, mobilização e conflito. Revista Iberoamericana de Turismo - RITUR, Penedo, Vol. 5, Número Especial, p. 169-179, abr. 2015.

BARCELlOS, Caco. Abusado: O Dono do Morro Dona Marta. Rio de Janeiro, Ed. Record. 2008. 349p.

BATISTA, Nilo. Ainda há tempo de salvar as Forças Armadas da cilada da militarização da segurança pública. In: BATISTA, Vera Malaguti et al. (Org.). Paz armada. Rio de Janeiro: Revan, Instituto Carioca de Criminologia, 2012. p. 47-54.

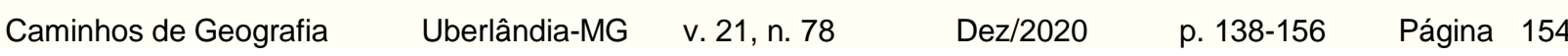


BAUMAN, Zygmunt. Globalização: as consequências humanas. Rio de Janeiro: Zahar, 1998, 148p.

BENI, Mário Carlos. Análise estrutural do turismo. São Paulo: Senac, 1999

BOTTINO, Caroline Melo. Favela à vista! Das primeiras expedições ao turismo organizado. In: XXIX Simpósio Nacional de História, 2017, Brasília. Anais do XXIX Simpócio Nacional de História - contra os preconceitos: história e democracia, 2017.

Brasil. Decreto №42.787, de 06 de Janeiro de 201. Disponível em: <http://www.silep.planejamento.rj.gov.br/decreto_42_787_-_060111.htm>. Acesso em 18 dez. 2019.

CALDEIRA, T. P. R. Enclaves fortificados: uma nova segregação urbana. Novos Estudos CEBRAP, São Paulo, n. 47, p. 155-176. 1997.

CORREA, Roberto Lobato. Trajetórias Geográficas. 2. ed. Rio de Janeiro: Bertrand Brasil, 2005. $302 p$.

CUNHA, Neiva Vieira de \& MELLO, Marco Antonio da Silva. Novos conflitos na cidade: A UPP e o processo de urbanização na favela. Dilemas: Revista de estudos de conflito e controle social, Rio de Janeiro, v. 4, n. 3, p. 371-401, jul.- set. 2011.

DEBORD, Guy. A sociedade do espetáculo. Rio de Janeiro: Contraponto, 1997, 240p.

FOUCAULT, Michel. Segurança, Território, População: curso dado no Collège de France (19771978). $1^{\text {a }}$ Edição. São Paulo: Martins Fontes, 2008.

FRANCO, Marielle. UPP - A redução da favela a três letras: uma análise da política de segurança pública do estado do Rio de Janeiro. (2014) Dissertação (mestrado em administração). Faculdade de Administração, Ciências Contábeis e Turismo, Universidade Federal Fluminense, Niterói.

FREIRE-MEDEIROS, Bianca. A construção da favela carioca como destino turístico. Rio de Janeiro: CPDOC, 2006.

. A favela que se vê e que se vende: reflexões e polêmicas em torno de um destino turístico.

Rev. bras. Ci. Soc., São Paulo, v. 22, n. 65, p. 61-72, Outubro, 2007. https://doi.org/10.1590/S0102$\underline{69092007000300006}$

Gringo na laje: produção, circulação e consumo da favela turística / Bianca Freire -. Medeiros. - Rio de Janeiro : Editora FGV, 2009.

FREIRE-MEDEIROS, Bianca; VILAROUCA, Márcio Grijó; MENEZES, Palloma. A POBREZA TURÍSTICA NO MERCADO DE PACIFICAÇÃO: reflexões a partir da experiência da Favela Santa Marta. Cad. CRH, Salvador , v. 29, n. 78, p. 571-586, dez. 2016 . Disponível em <http://www.scielo.br/scielo.php?script=sci_arttext\&pid=S010349792016000300571\&lng=pt\&nrm=iso> . acessos em 22 out. 2018. http://dx.doi.org/10.1590/s0103-49792016000300010.

HARVEY, David. A Produção Capitalista do Espaço. São Paulo: Annablume, 2005, 252p.

. O enigma do capital: e as crises do capitalismo / David Harvey; tradução de Joao Alexandre Peschanski. - São Paulo, SP: Boitempo, 2011.

LUKÁCS, György. Prolegômenos para uma ontologia do ser social: questões de princípios para uma ontologia hoje tornada possível. Tradução de Lya Luft e Rodnei Nascimento. São Paulo: Boitempo, 2010. 414p.

MARTONI, Rodrigo Meira. Por uma ontologia do espaço turístico: contribuições para uma consciência do real e do possível. 2014. 334 f. Tese (doutorado do programa de Pós-Graduação em Geografia) Universidade Federal do Paraná, Curitiba, 2014.

MARX, Karl. O 18 de brumário de Luís Bonaparte. Tradução e notas Nélio Schneider; prólogo Hebert Marcuse. São Paulo: Boitempo, 2011 (Coleção Marx-Engels). 174 p.

MASCARENHAS, G. Cenários contemporâneos da urbanização turística Caderno Virtual de Turismo, vol. 4, núm. 4, 2004, pp. 1-11 Universidade Federal do Rio de Janeiro Río de Janeiro, Brasil.

Cidade mercadoria, cidade-vitrine, cidade turística: a espetacularização do urbano nos megaeventos esportivos. Caderno Virtual de Turismo. Edição especial: Hospitalidade e políticas públicas em turismo. Rio de Janeiro, v. 14, supl.1, s.52-s.65, nov. (2014a). 
Espetáculo e distopia: natureza e tensões do urbanismo olímpico contemporâneo. Anais da II Conferência Internacional Megaeventos e a cidade, (2014b), Rio de Janeiro, p.43-57.

. A produção da cidade olímpica e os sinais da crise do modelo globalitário. Geousp - Espaço e Tempo (Online), v. 20, n. 1, p. 52-68, mês. (2016b). ISSN2179-0892. Disponível em: http://www.revistas.usp.br/geousp/article/view/107148. DOI: http://dx.doi.org/10.11606/issn.21790892.geousp.2016.107148.

MOESCH, Marutschka Martini. A produção do saber turístico. São Paulo: Contexto, 2000. 140p.

Morro Santa Marta tem primeiro tiroteio pós-UPP. Veja, Rio de Janeiro, 29 de mai de 2015. Disponível em: https://veja.abril.com.br/brasil/morro-santa-marta-tem-primeiro-tiroteio-pos-upp

SANTOS, Milton. A Natureza do Espaço: Técnica e Tempo, Razão e Emoção / Milton Santos. - 4. ed. 2. reimpr. - São Paulo: Editora da Universidade de São Paulo, 2006.

URANI, A. Salto qualitativo na retomada de desenvolvimento. Jornal dos Economistas, Rio de Janeiro, n. 245, p. 5-6, dez. 2009.

VALLADARES, Lícia. A gênese da favela carioca. A produção anterior às ciências sociais. Rev. bras. Ci. Soc. [online]. 2000, vol.15, n.44, pp.05-34. https://doi.org/10.1590/S0102$\underline{69092000000300001}$

Recebido em: 10/03/2020

Aceito para publicação em: 06/08/2020 